\title{
Botany
}

American Journal of Botany 99(11): 1778-1792. 2012.

\section{Evolution OF MORPHOLOGICAL TRAITS IN VERBENACEAE ${ }^{1}$}

\author{
Nataly O’Leary ${ }^{2,6}$, Carolina Isabel Calviño ${ }^{3}$, Susana Martínez ${ }^{4}$, Pat Lu-Irving ${ }^{5}$, \\ Richard G. Olmstead ${ }^{5}$, and Maria Ema Múlgura ${ }^{2}$
}

\begin{abstract}
${ }^{2}$ Instituto de Botánica Darwinion, Labardén 200, CC 22, San Isidro, Buenos Aires, Argentina; ${ }^{3}$ INIBIOMA, CONICETUniversidad Nacional del Comahue, Bariloche, Argentina; ${ }^{4}$ Facultad de Ciencias Exactas y Naturales, Universidad de Buenos Aires, Argentina; and ${ }^{5}$ Department of Biology and Burke Museum, University of Washington, Seattle, Washington 98195 USA.
\end{abstract}

- Premise of the study: A new infrafamilial circumscription of the Verbenaceae with eight tribes: Casselieae, Citharexyleae, Duranteae, Lantaneae, Neospartoneae, Petreeae, Priveae, and Verbeneae, has been recently proposed, on the basis of molecular phylogenetic studies. Two genera, Dipyrena and Rhaphithamnus, remain unplaced. The aim of this work is to reconstruct the evolutionary history of morphological characters traditionally employed in the classification of the Verbenaceae, with special attention to tribes Verbeneae and Lantaneae.

- Methods: Twenty-one characters, related to habit and vegetative morphology, inflorescence and floral morphology, ovary and fruit morphology, as well as chromosome number, were optimized over a molecular phylogeny of Verbenaceae.

- Key Results: All tribes are supported by at least one morphological trait except tribes Duranteae and Citharexyleae. Suffrutescent habit, sessile flowers, and four cluses are synapomorphies for tribe Verbeneae. Gynoecium with short style and entire stigma are synapomorphic traits for tribe Lantaneae. Sessile flowers and unicarpellate ovaries are morphological synapomorphies for the new tribe Neospartoneae. Suffrutescent habit is a synapomorphic trait for tribe Priveae. Homothetic pleiobotrya and absence of the adaxial staminode are synapomorphic traits for tribe Casselieae. Undivided fleshy fruits are probably a synapomorphic trait for tribe Petreeae. Putative plesiomorphies for the ancestor of the Verbenaceae are discussed as well as synapomorphic traits within other Verbenaceae clades.

- Conclusions: Many of the characters traditionally employed in classification have proven to be very homoplastic, or have been shown not to support relationships within the family. Moreover, traditional assumptions concerning character polarity have in some cases been shown to be incorrect.

Key words: Character evolution; molecular phylogeny; optimization; tribes.

Verbenaceae, as recently circumscribed, comprises approximately 32 genera and 840 species (Cantino et al., 1992; Atkins, 2004; Marx et al., 2010). They are an important element in the floras of North and South America, especially in warm temperate and tropical regions. The Verbenaceae includes shrubs or small trees, suffruticose plants, and herbs, and occurs in open and forested, xeric and mesic, habitats.

Recent molecular phylogenetic studies (Marx et al., 2010; Yuan et al., 2010) identified the major lineages in the family and resolved generic relationships throughout most of the group. This resulted in a revised classification for Verbenaceae, dividing the family into eight tribes (Marx et al., 2010). Within Verbenaceae, tribes Verbeneae and Lantaneae represent relatively recent radiations with historically uncertain generic boundaries. The five genera and approximately 175 species of the tribe Verbeneae often have been combined under Verbena in earlier treatments (Schauer, 1847; Briquet, 1895; Perry, 1933; Troncoso, 1974). Most species of Verbeneae

\footnotetext{
${ }^{1}$ Manuscript received 20 March 2012; revision accepted 24 September 2012.

The authors thank V. Thode for information on tribe Duranteae. This contribution was supported by the Consejo Nacional de Investigaciones Científicas y Técnicas (PIP 11220080100177/09, PIP 112-200901-00282 to MM and NO'L), Universidad Nacional del Comahue (PIN B149 to CC), Académia Nacional de Ciencia y Técnica (PICT 2007-1482 to CC), National Science Foundation (DEB 0542493 and DEB 1020369 to RGO).

${ }^{6}$ Author for correspondence (e-mail: noleary@darwin.edu.ar)
}

doi:10.3732/ajb.1200123 are found in temperate North or South America. Several recent molecular phylogenetic studies of Verbeneae (O'Leary et al., 2009; Yuan and Olmstead, 2008a, b) have resulted in recircumscriptions of genera, and a robust phylogenetic backbone for this tribe. Similarly, the approximately 275 species of Lantaneae have been sorted traditionally into genera on the basis of a few easily observable traits (e.g., fruit type and inflorescence architecture) into seven to nine genera (e.g., Atkins, 2004). Most species from this tribe are found in tropical North or South America, with a secondary radiation in Africa. Ongoing work on Lantaneae also indicates that generic circumscriptions need to be reassessed (Marx et al., 2010; Lu-Irving and Olmstead, in press).

Molecular phylogenetic studies of Verbenaceae (Marx et al., 2010; Yuan et al., 2010) found that traditional divisions of the family into tribes (e.g., Atkins, 2004), based on various combinations of morphological traits, were severely discordant with phylogenetic relationships. Similarly, at the generic level within Verbeneae and Lantaneae, morphology-based delimitations have been shown to be discordant with phylogenetic relationships, both with respect to which genera comprise each tribe and generic circumscriptions. Thus, the major objectives of this study are to identify morphological characters that support phylogenetic relationships within Verbenaceae as inferred on the basis of molecular data (Marx et al., 2010; Yuan et al., 2010; O'Leary et al., 2009; Lu-Irving and Olmstead, in press), including, where possible, those clades recognized as tribes, and to reconstruct the evolutionary history of those morphological characters traditionally used in the systematics of the family. 


\section{MATERIALS AND METHODS}

Accessions examined-Representatives of all tribes within Verbenaceae were examined. In all cases, species were selected to span the morphological variation within each genus (Appendix S1, see Supplemental Data with the online version of this article). All genera included in the family-wide study (Marx et al., 2010) were sampled (including more than one species of most larger genera): Verbeneae - 33 species, Lantaneae - 29 species, Casselieae - 4 species, Neospartoneae -5 species, Duranteae -8 species, Priveae -3 species, Citharexyleae -3 species, and Petreeae -1 species. The monotypic Dipyrena and one of the two species of Rhaphithamnus, genera not assigned to tribe, were examined. The only exceptions were the monotypic Xolocotzia (Petreeae), for which no material was available, and the monotypic Hierobotana, which was also missing in previous phylogenetic studies of tribe Verbeneae (Yuan and Olmstead, 2008a,b; O'Leary et al., 2009) and its phylogenetic position is still uncertain (Marx et al., 2010).

Morphological data-Twenty discrete morphological characters and one cytological character were scored based on our experiences working with the group, observations of herbarium specimens and taxonomic literature, including all major treatments of the family and revisions of its genera (Schauer, 1847; Briquet, 1895; Troncoso, 1974; Atkins, 2004; Botta, 1989; O’Leary et al., 2007a, 2008, 2010, 2011; O’Leary and Múlgura, 2010; Peralta, 2010). These 21 characters (Appendix 1) represent habitat and vegetative morphology (characters $1-2)$, inflorescence and floral morphology (characters $3-13$ ), ovary and fruit morphology (characters $14-20$ ), and chromosome number (character 21). All characters were treated as unordered, 14 characters were binary, and 7 were multistate (Appendix S1, see Supplemental Data with the online version of this article). For a few taxa (e.g., the genus Chascanum), some character states could not be assessed because of absence of existing material and literature information. Therefore, these states were scored as missing. Similarly, cytological data were missing for several taxa. Since the data are not being used for phylogenetic inference, some mutually dependent characters (chars. 17 -19) were employed, to better illustrate the evolution of traits.

Evolution of morphological characters-A summary tree depicting relationships within the family was assembled from the family-wide studies (Marx et al., 2010; Yuan et al., 2010), in combination with more focused studies of Verbeneae (Yuan and Olmstead, 2008a,b; O'Leary et al., 2009) and Lantaneae (Lu-Irving and Olmstead, in press). This tree was employed as a phylogenetic hypothesis on which to reconstruct character evolution. The portion of the tree below the node connecting Verbeneae and Lantaneae reflects the congruence of chloroplast (Marx et al., 2010) and nuclear (Yuan et al., 2010) genome studies. The placement of Dipyrena in a trichotomy with Verbeneae and Lantaneae, reflects the conflict in its positions in those two studies. Verbena and Glandularia are constrained to monophyly based on phylogenetic inference from nuclear genes, because the cpDNA tree for Verbeneae shows evidence for multiple chloroplast transfer events (Yuan and Olmstead, 2008a,b; O'Leary et al., 2009).

To assess patterns of evolution of the 21 morphological and chromosome characters, we optimized each character under a parsimony criterion onto the summary phylogenetic tree using the program Mesquite version 2.72 (Maddison and Maddison, 2005). To identify those morphological characters that support relationships based on molecular data, we recorded all morphological synapomorphies at each node. To further evaluate the utility of morphological characters in delimiting monophyletic groups and their degree of homoplasy, the molecularbased tree was used to infer the number of evolutionary steps of these characters using the program Mesquite version 2.72 (Maddison and Maddison, 2005).

The phylogeny of the Verbenaceae is now well-resolved with respect to most generic relationships and the primary lineages within the family. The relationships among families in the portion of Lamiales where Verbenaceae is found however, still remain unclear, or weakly supported (Schaferhoff et al., 2010), with some support for the small African family, Thomandersiaceae, as sister to Verbenaceae (Soltis et al., 2011; Refulio and Olmstead, unpublished data). Given the uncertainty of outgroup relationships, character optimizations are restricted to the ingroup, which will leave the ancestral node reconstructions unresolved in some instances.

\section{RESULTS}

Evolution of morphological characters-The number of evolutionary steps for each of the 21 characters is presented in Fig. 1. Three of the 21 characters considered are not homoplastic, these are: (1) pair of adaxial lateral stamens (character 10); (2) style base (char. 13); and (3) separation of the fruit longitudinally along the transverse plane segregating carpels (char. 19). Among the most homoplastic characters (10-14 steps) are: (1) habit (char. 1); (2) leaf incision (char. 2); (3) presence of axillary florescences (char. 4); (4) type of fruit (char. 16); (5) number of units from division of the fruit (char. 17); (6) separation of the fruit longitudinally along the medial plane of the ovary (char. 18); and (7) cluse or mericarp base (char. 20). Reconstruction of the evolution of each character is presented in the Discussion (Figs. 2-10, Appendices S2-S15, see Supplemental Data with the online version of this article). The examined morphological characters that support monophyletic groups are mapped onto a simplified tree that summarizes the relationships among the genera (Fig. 11).

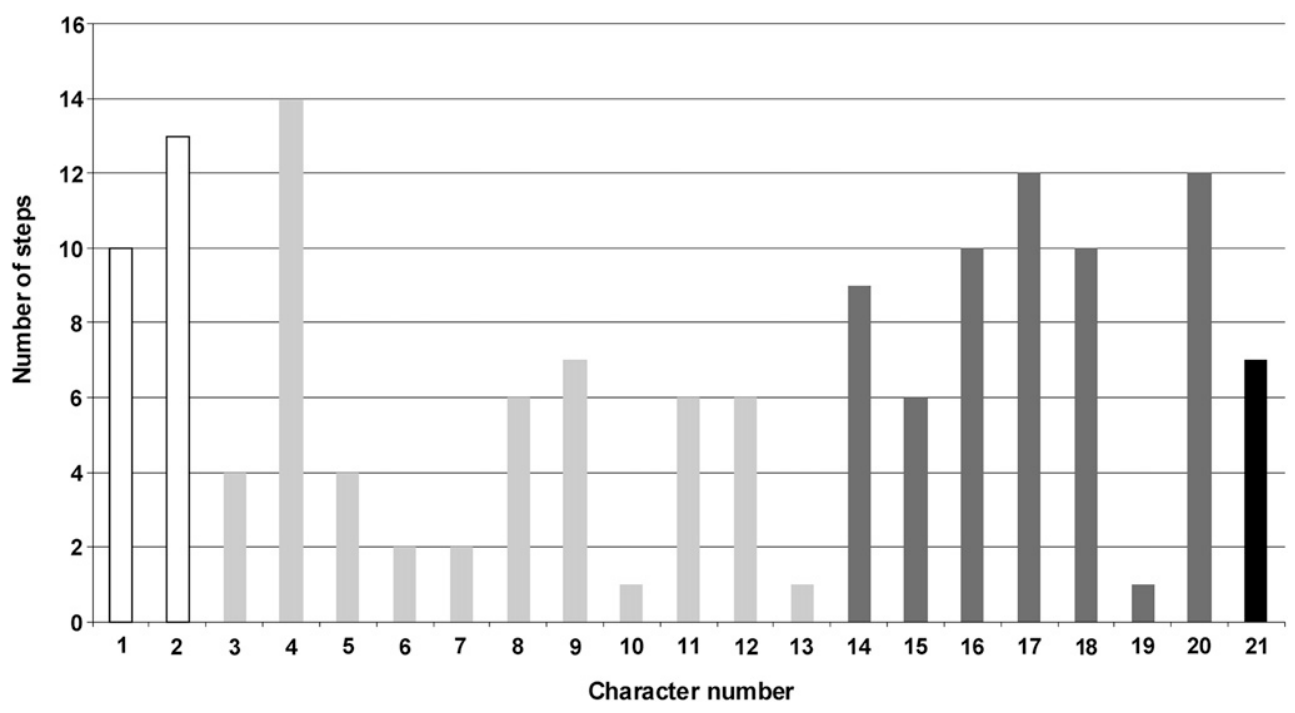

Fig. 1. Number of evolutionary steps of each of the 21 characters. Bars represent the following classes of characters shown in Appendix 1: life history and vegetative morphology (white bars); inflorescence and floral morphology (light-gray bars); ovary and fruit morphology (dark-gray bars); and chromosome number (black bar). Character numbers refer to those presented in Appendix 1. 


\section{DISCUSSION}

Habit and vegetative morphology-Most species of Verbenaceae are woody, with Glandularia, Verbena, Phyla, and Pitraea the only herbaceous genera (char. 1) (Appendix S2, see Supplemental Data with the online version of this article). Woodiness in Verbenaceae is represented by those plants that are small trees, shrubs, lianas, or suffruticose plants. Shrubs or small trees are plesiomorphic in most Verbenaceae tribes. The suffrutescent habit has apparently evolved from shrubs or small trees at least five times within the family, constituting a synapomorphy for the clade that includes Bouchea, Chascanum, and Stachytarpheta (within Duranteae), the clade of Tamonea plus Casselia (within Casselieae), Priveae, and Verbeneae. Within Lantaneae the suffrutescent habit appears in certain taxa, such as Lippia dulcis Trevir. and Burroughsia. The herbaceous habit has probably evolved independently at least three times in Pitraea (Priveae), Phyla (Lantaneae), and within the tribe Verbeneae. No evidence of a reversion from herbaceous to woody habit has been found in Verbenaceae, but the suffrutescent habit appears to have reverted to shrubby habit in Junellia. Although examples of woodiness evolving from herbaceous ancestors are found in other families such as Apiaceae (Calviño et al., 2006, 2008), Pericallis in the Asteraceae (Panero et al., 1999), or Echium in the Boraginaceae (Böhle et al., 1996), Verbenaceae exemplifies the common evolutionary trend of unidirectional evolution from woody to herbaceous. The suffrutescent habit is a synapomorphy for Verbeneae and found in the basal grade formed by $\mathrm{Mul}$ guraea and the ancestor of Junellia. In the ancestor of Verbena plus Glandularia a shift to herbaceous habit occurred, constituting a synapomorphy for this clade. A similar shift occurred in Priveae, where the suffrutescent habit is a synapomorphy for the tribe and a shift to herbaceous habit is found in Pitraea. These results suggest that in Verbenaceae herbs have always evolved from suffruticose ancestors, and that suffruticose plants have always evolved from ancestors that were shrubs or small trees. The only case where this is not confirmed is the reversion from a suffruticose ancestor to a shrubby habit within Junellia. This reversion was suggested by Sanders (2001) in that woody growth in Junellia might be a secondary development.

Leaf blades in Verbenaceae are typically entire. However, divided leaf blades may have evolved from entire leaf blades independently in a species of Bouchea (Duranteae) and in Burroughsia (Lantaneae) and several times within Verbeneae (char. 2) (Appendix S3, see Supplemental Data with the online version of this article). Reversions to entire leaf blades appear to have occurred only within Glandularia. Sanders (2001) suggested Verbena and Glandularia could be distinguished from the rest of the Verbenaceae by their more divided leaf blades. However, leaf incision shows a high level of homoplasy particularly

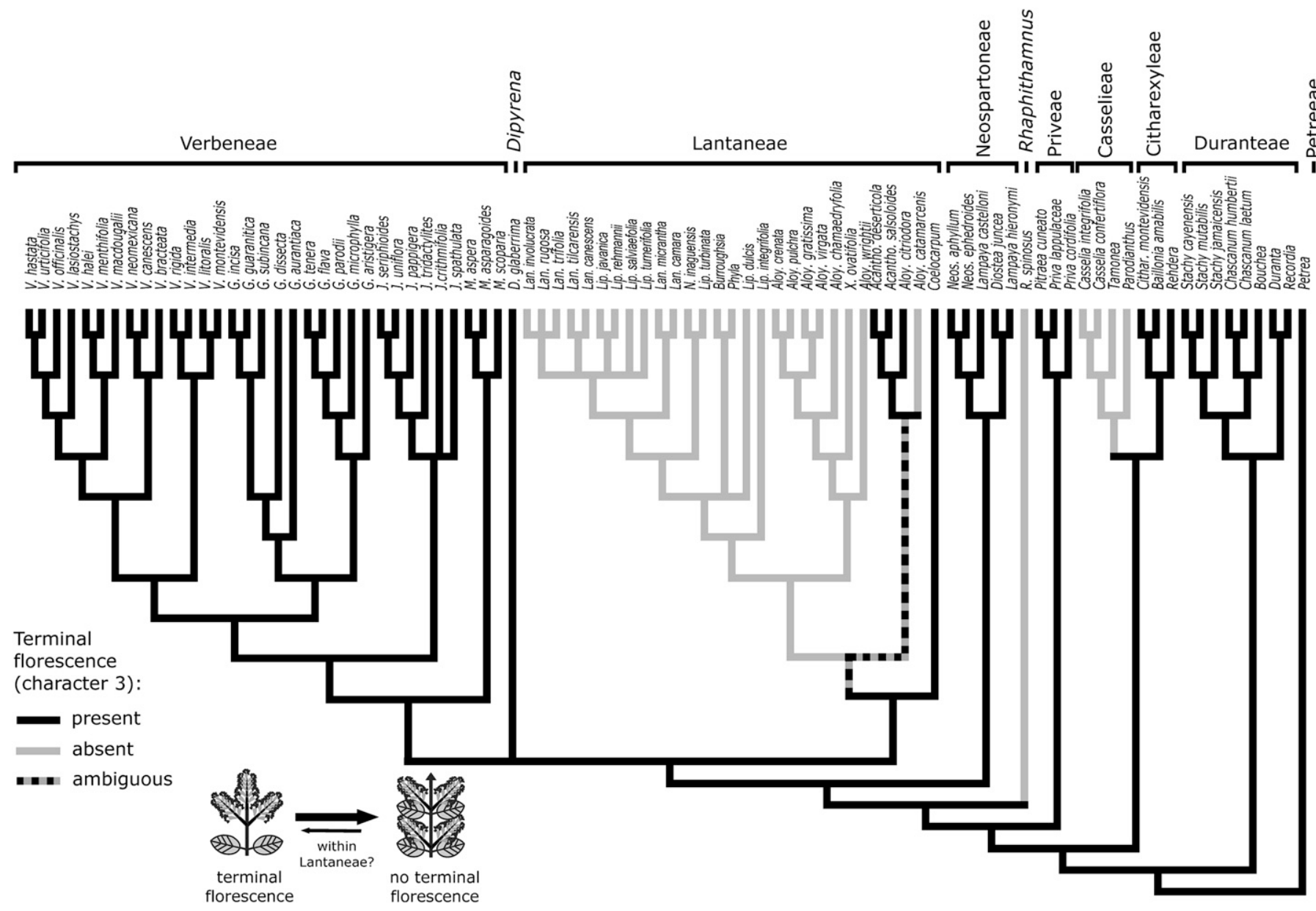

Fig. 2. Evolution of the inflorescence, presence or absence of terminal florescence (character 3). This character is reconstructed as having four steps within Verbenaceae. 
within Verbeneae (at least 10 changes). Nevertheless, the character of divided leaf blades is a synapomorphy for Glandularia, whereas that of entire leaf blades constitutes a plesiomorphy for Verbena, where divided leaves only appear in the North American Verbena clade.

Inflorescence and floral morphology-The presence of a terminal florescence is the plesiomorphic state for the family (char. 3, Fig. 2). It can take the form of a spike or raceme, found either with or without axillary florescences in Verbenaceae, and referred to as heterothetic pleiobotrya or monobotrya, respectively. The shift to the absence of a terminal florescence, referred to here as a homothetic pleiobotrya, seems to have occurred at least four times independently within Verbenaceae, once in the ancestor of tribe Casselieae, once in the ancestor of the genus Rhaphithamnus, and twice within Lantaneae. Although reconstruction is ambiguous for the ancestor of Lantaneae, excluding Coelocarpum, the loss of the terminal florescence and its regain is less probable than two parallel losses, so we consider this last option to be more likely. Within Lantaneae, presence of a terminal florescence is the plesiomorphic state, found only in Coelocarpum and the clade Aloysia + Acantholippia, with the exception of Aloysia catamarcensis
Moldenke. Loss of the terminal florescence, constitutes a synapomorphy for all the remaining Lantaneae, i.e., the Lippia + Lantana and Aloysia + Xeroaloysia clade. Within the tribe Verbeneae all members share the plesiomorphic state, e.g., inflorescences with a terminal florescence.

Presence of axillary florescences (char. 4, Fig. 3) is the plesiomorphic and most frequent state for Verbenaceae. The character is ambiguously reconstructed and is the most homoplastic of all characters, with at least 14 steps. Loss of axillary florescences, (giving rise to monobotrya from heterothetic pleiobotrya), likely occurred unambiguously and independently several times within the family, e.g., in Recordia (Duranteae), Pitraea (Priveae), and Acantholippia (Lantaneae). All other shifts are ambiguously reconstructed and therefore reversions to presence of axillary florescences cannot be ruled out.

Classical views of inflorescence evolution (Fig. 4A) suggest that compound inflorescences with axillary and terminal florescences (heterothetic pleiobotrya) gave rise, on the one hand, to compound truncate inflorescences with only axillary florescences (homothetic pleiobotrya) by loss of the terminal florescence, and, on the other hand, simple forms reduced to one terminal florescence (monobotrya), by loss of axillary florescences (Sell, 1976, 1980; Troll, 1964, 1969). Martínez et al. (1996) and Múlgura

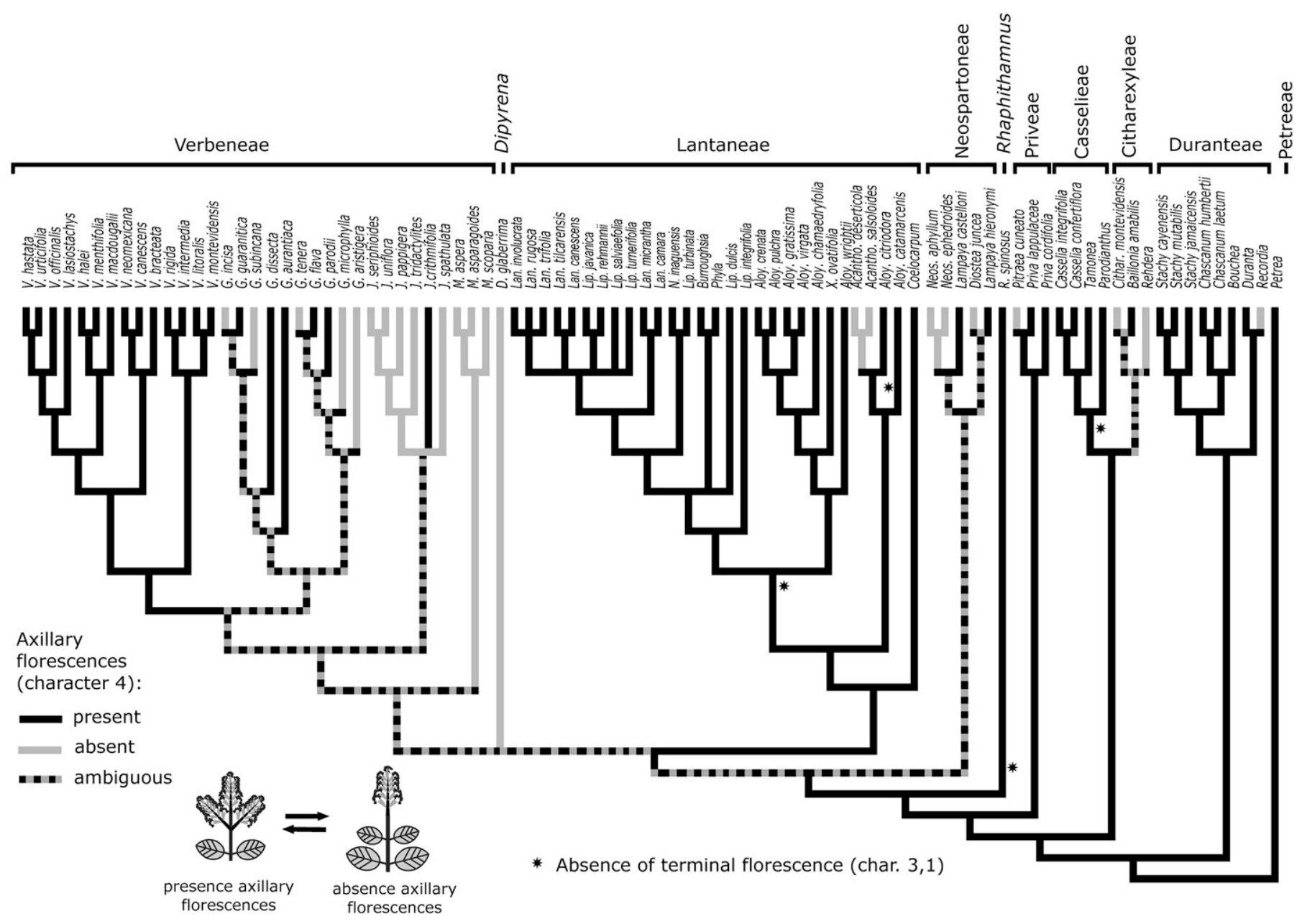

Fig. 3. Evolution of the inflorescence, presence or absence of axillary florescences (character 4). This character is reconstructed as having a minimum of 14 steps within Verbenaceae. 


\section{A Classical hypothesis}

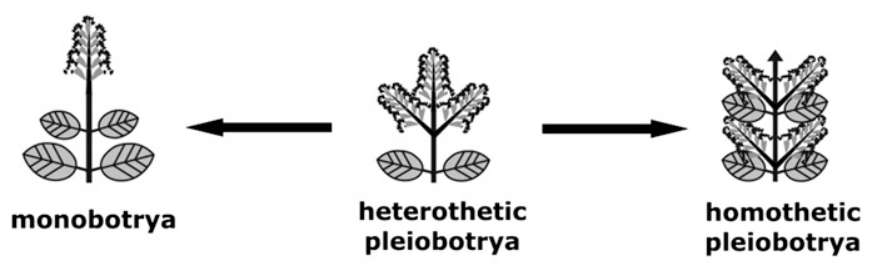

B Reconstruction of characters 3 and 4

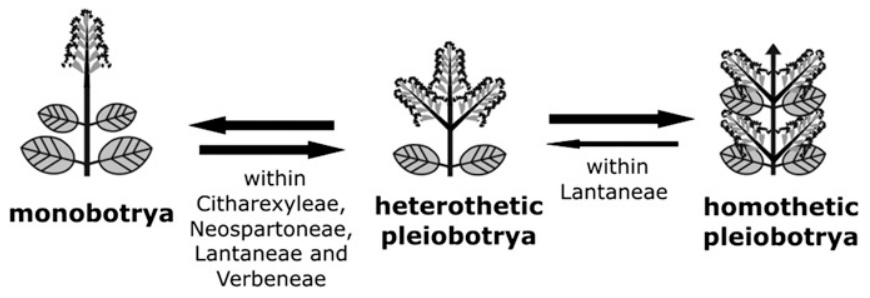

Fig. 4. Schematic representation of inflorescence evolution in Verbenaceae according to (A) classical hypothesis (Troll, 1964,1969; Sell, 1976, 1980) and (B) maximum parsimony reconstruction of characters 3 and 4. Within tribe Lantaneae reversion to heterothetic pleiobotrya cannot be ruled out. Within tribes Citharexyleae, Neospartoneae, Lantaneae and Verbeneae a shift from monobotrya to heterothetic pleiobotrya are equally likely.

et al. $(1998,2002)$ suggested that this evolutionary trend exists in Verbenaceae, as well. By looking at the reconstructions of characters 3 and 4 together (Figs. 2,3) it is possible to confirm that homothetic pleiobotrya found in Casselieae, Rhaphithamnus, Aloysia catamarcensis (Lantaneae) and a large clade within Lantaneae, are always derived from heterothetic pleiobotrya. Homothetic pleiobotrya can therefore be considered a final step, although reversion to heterothetic pleiobotrya cannot be ruled out within Lantaneae. This analysis also confirms the derivation of monobotrya from heterothetic pleiobotrya by loss of axillary florescences. However, unexpectedly, according to classical assumptions about the evolution of inflorescences, reversions from monobotrya to heterothetic pleiobotrya also occur (Fig. 4B). The frequency with which these character transformations have occurred in Verbenaceae renders inflorescence architecture to be of limited value for defining tribal groups.

Pedicellate flowers (char. 5) (Appendix S4, see Supplementary Data with the online version of this article) are the plesiomorphic state for the family, found in all members of the first diverging tribes from Petreeae to Rhaphithamnus, with the exception of a clade within Duranteae where sessile flowers are found (Stachytarpheta + Bouchea + Chascanum). Reconstruction of this trait is ambiguous along the stem of the tree above the divergence of Rhaphithamnus, with pedicellate flowers found only in Coelocarpum and Dipyrena, and the flowers being sessile in the rest of the taxa. For the tribe Verbeneae, presence of sessile flowers constitutes either a plesiomorphy or a synapomorphy, the latter having been suggested by Sanders (2001).

Calyx dentition (char. 6) (Appendix S5, see Supplementary Data with the online version of this article) has been used traditionally as a diagnostic trait within the family Verbenaceae (Schauer, 1847; Troncoso, 1974; Botta, 1979; Atkins, 2004). A five-toothed calyx (Appendix S6A, see Supplementary Data with the online version of this article) is the plesiomorphic state, and found in most members of the family with the exception of Lantaneae. In this tribe, the clade of Lippia + Lantana has a bilobed calyx, constitut- ing a nonhomoplasious synapomorphy for this clade (Appendices S5, S6C, see Supplementary Data with the online version of this article), whereas the Aloysia pro parte + Xeroaloysia and the Aloysia pro parte + Acantholippia clades both have 4-toothed calyces (Appendix S6B, see Supplementary Data with the online version of this article). Since Coelocarpum is the only member of this tribe with a 5-toothed calyx and is sister to the rest of the clade, a 5-toothed calyx is plesiomorphic for Lantaneae, within which a shift to a 4-toothed calyx occurred once and a subsequent shift to a bilobed calyx resulted in a synapomorphy for the Lippia + Lantana clade. This suggests an apparent progressive reduction in calyx teeth from five to four to two.

The presence of an anther connective tissue surpassing the theca is the single morphological trait that supports the monophyly of Mulguraea (char. 7) (Appendix S7, see Supplementary Data with the online version of this article), a genus recently segregated from Junellia (O'Leary et al., 2009). This character state also occurs independently in Bouchea (Duranteae), but could not be confirmed in its sister genus Chascanum.

A glandular anther connective appendix (char. 8) (Appendix S8, see Supplementary Data with the online version of this article) seems to have evolved independently at least five times in Verbenaceae. Within the tribe Verbeneae the presence of a glandular appendix in the anthers is a synapomorphy for Glandularia, but this trait has been lost in Glandularia incisa (Hook.) Tronc. but also appeared independently in Junellia crithmifolia (Gillies \& Hook.) N. O'Leary \& P. Peralta and related species once assigned to Glandularia (O'Leary et al., 2009). This character has been used traditionally to differentiate between Verbena and Glandularia (Schnack, 1964) and it constitutes a synapomorphy for Glandularia, whereas Verbena bears the plesiomorphic state, e.g., absence of an anther connective appendix. Outside the Verbeneae, presence of a glandular anther connective appendix also appears at least 3 times independently in species from tribe Lantaneae, but where it is not useful to define groups.

Plants of Verbenaceae generally have four fertile stamens. A fifth structure in the staminal whorl is sometimes present in the adaxial (or ventral) position and is always sterile. This staminode (char. 9) (Appendix S9, see Supplementary Data with the online version of this article), is found in at least one genus from each of the first diverging tribes of Verbenaceae from Petreeae to Neospartoneae, and is present also in the family Thomandersiaceae (Wortley et al., 2007; Refulio and Olmstead, unpublished data). The staminode character is highly homoplastic, with at least 7 changes, and its reconstruction is ambiguous. The probable ancestors of tribes Duranteae, Citharexyleae, Casselieae, Priveae, and Neospartoneae could either have had a staminode or not. However, in Lantaneae, Verbeneae, and the genus Dipyrena, the staminode is always absent, leaving only the four staminal structures in the androecium. The absence of the staminode is plesiomorphic for Verbeneae, despite the suggestion by Sanders (2001) that absence of the staminode is a synapomorphy for Verbeneae.

In the possible ancestor of Stachytarpheta, within Duranteae, the fifth staminode is absent (plesiomorphic state, char. 9), and a unique condition from which the two abaxial lateral stamens are sterile probably arose. The monotypic genus Hierobotana (not included here), which has only two stamens and no staminodes, and Stachytarpheta are the only genera of Verbenaceae with two fertile stamens.

The length of the style relative to the length of the ovary (char. 11) (Appendix S10, see Supplementary Data with the online version of this article) has been a diagnostic trait used to distinguish Verbena from Glandularia (Schnack and Covas, 
1944, 1946; Schnack, 1964; Troncoso, 1974; Botta, 1993). Most of the early diverging tribes of Verbenaceae (Petreeae, Citharexyleae, Casselieae, and Priveae), have short styles (reconstruction of the character in Duranteae is ambiguous), and this character is inferred to be ancestral in the family. Long styles appeared prior to the divergence of Rhaphithamnus, but short styles are likely present in both the ancestors of Lantaneae and the genus Verbena. The character of short styles constitutes a synapomorphy for Lantaneae and for Verbena. In spite of its homoplastic nature within Verbenaceae, it is a good diagnostic trait to distinguish Verbena from other members of Verbeneae.

An entire, unlobed stigma is the plesiomorphic state in Verbenaceae, and present, with few exceptions, in tribes Petreeae, Duranteae, Citharexyleae, and Casselieae. A bilobed stigma has appeared independently at least four times in Verbenaceae from apparent ancestors with an entire stigma (char. 12) (Appendix S11, see Supplementary Data with the online version of this article), e.g., in Recordia and Bouchea (Duranteae, where it is uncertain in Chascanum), Parodianthus (Casselieae), and in the probable ancestor of tribes Priveae to Verbeneae. Reversion from a bilobed to entire stigma supports the monophyly of $\mathrm{Neo}$ sparton and of Lantaneae, where an entire stigma constitutes a synapomorphy. All members of Verbeneae have bilobed stigmas, a trait that several authors have employed as a diagnostic trait for the tribe (Sanders, 2001; Atkins, 2004). However, it constitutes a plesiomorphic trait for Verbeneae.

Flowers in the Verbenaceae have a slender style base (char. 13) (Appendices S12, S13, see Supplementary Data with the online version of this article), with the exception of several Junellia species, which have enlarged style bases. Within Junellia this character has been used to distinguish the subgenera Junellia and Thryothamnus (Botta, 1989; Peralta et al., 2008). Its reconstruction on the phylogeny shows that the presence of an enlarged style base is a nonhomoplasious synapomorphy for the clade of J. tridactylites (Lag.) Moldenke to Junellia seriphioides (Gillies \& Hook. ex Hook.) Moldenke, traditionally treated in Junellia subgenus Junellia. In contrast, both Junellia spathulata (Gillies \& Hook. ex Hook.) Moldenke, traditionally treated under Junellia subgenus Thryothamnus (Botta, 1989), and J. crithmifolia (formerly in Glandularia, but recently combined under Junellia by O'Leary et al., 2009) have slender style bases. Thus, the enlargement of the style base appears to be a diagnostic trait for subgenus Junellia.

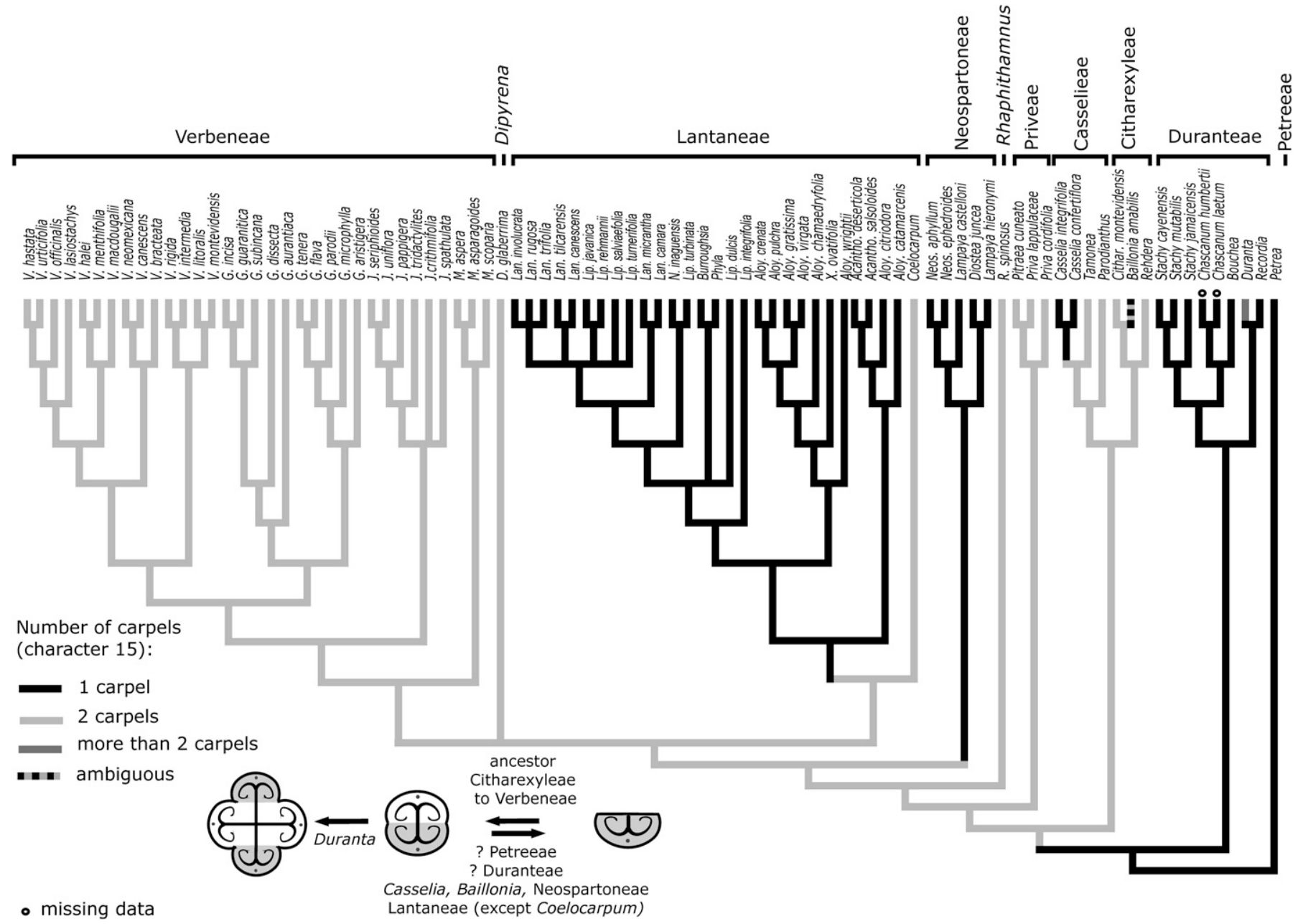

Fig. 5. Evolution of number of carpels (character 15). This character is reconstructed as having seven steps within Verbenaceae (comparison with related families and developmental studies, cited in the text, suggests that both tribes Petreeae and Duranteae represent independent reduction in carpel number). 
Ovary and fruit morphology - The calyx completely covering the fruit (char. 14) (Appendix S14, see Supplementary Data with the online version of this article), is a plesiomorphic character for all Verbenaceae tribes, except Citharexyleae and Casselieae, where it is ambiguously resolved. The transformation to a calyx not fully enclosing the fruit has occurred at least 6 times independently, e.g., in Recordia and Bouchea (Duranteae), Phyla (Lantaneae), Dipyrena, and possibly in the ancestor of the clade comprising Citharexyleae + Casselieae. In Rehdera (Citharexyleae), the calyx does not persist in the fruit. Despite its homoplastic nature, this character is useful to distinguish the tribe Verbeneae, with the plesiomorphic state, from its likely sister taxon Dipyrena glaberrima (Gillies \& Hook. ex Hook.) Hook., where the calyx only partially covers the fruit at maturity.

The number of carpels (char. 15, Fig. 5) in Verbenaceae is one or two, except in Duranta, which typically has four carpels, and/or occasionally five. Bicarpellate ovaries predominate in Lamiales, including Thomandersiaceae (Wortley et al., 2007; Soltis et al., 2011; Refulio and Olmstead, unpublished data). When observed in Verbenaceae, anatomical evidence suggests that the occurrence of a single carpel arose through the abortion of one carpel early in development (Junell, 1934; Atkins, 2004). Thus, bicarpellate ovaries are likely to be ancestral in Verbenaceae, despite the fact that two early diverging lineages (Petreeae and Duranteae) have unicarpellate ovaries at maturity. The presence of two developed carpels is inferred throughout the stem of the tree above the divergence of Petreeae and Duranteae. Reduction to one carpel occurred at least 4 other times in the family; (1) in Baillonia (Citharexyleae); (2) in Casselia; and (3) in the probable ancestors of Neospartoneae and Lantaneae, excluding Coelocarpum. In both Verbeneae and Lantaneae the presence of a bicarpellate ovary is a plesiomorphy.

In Verbenaceae the most frequent type of fruit (char. 16, Fig. 6) is a dry schizocarp, but some members of the family have fleshy drupaceous fruits with internal pyrenes. This character shows a high level of homoplasy with the fleshy fruit having evolved independently at least 8-10 times within Verbenaceae from dryfruited ancestors. Within Lantaneae, the lack of resolution inhibits an unambiguous reconstruction of this character, but multiple origins of fleshy fruits are evident (Lu-Irving and Olmstead, in press). Schauer (1847) reunited several genera under an enlarged tribe Verbeneae (including Lippia, Aloysia, and Priva) on the basis of their dry fruits, however, this trait is plesiomorphic for all these taxa. Without outgroups in our analysis, it is impossible to unambiguously reconstruct the morphology of the ancestor of Verbenaceae. Yet, by examining fruit variation of families inferred to be close to Verbenaceae (Schaferhoff et al., 2010; Soltis et al., 2011; Refulio and Olmstead, unpublished data), we found that most of them have dry fruits, and therefore, a dry fruit is more likely for the ancestor of Verbenaceae. Fleshy fruits are

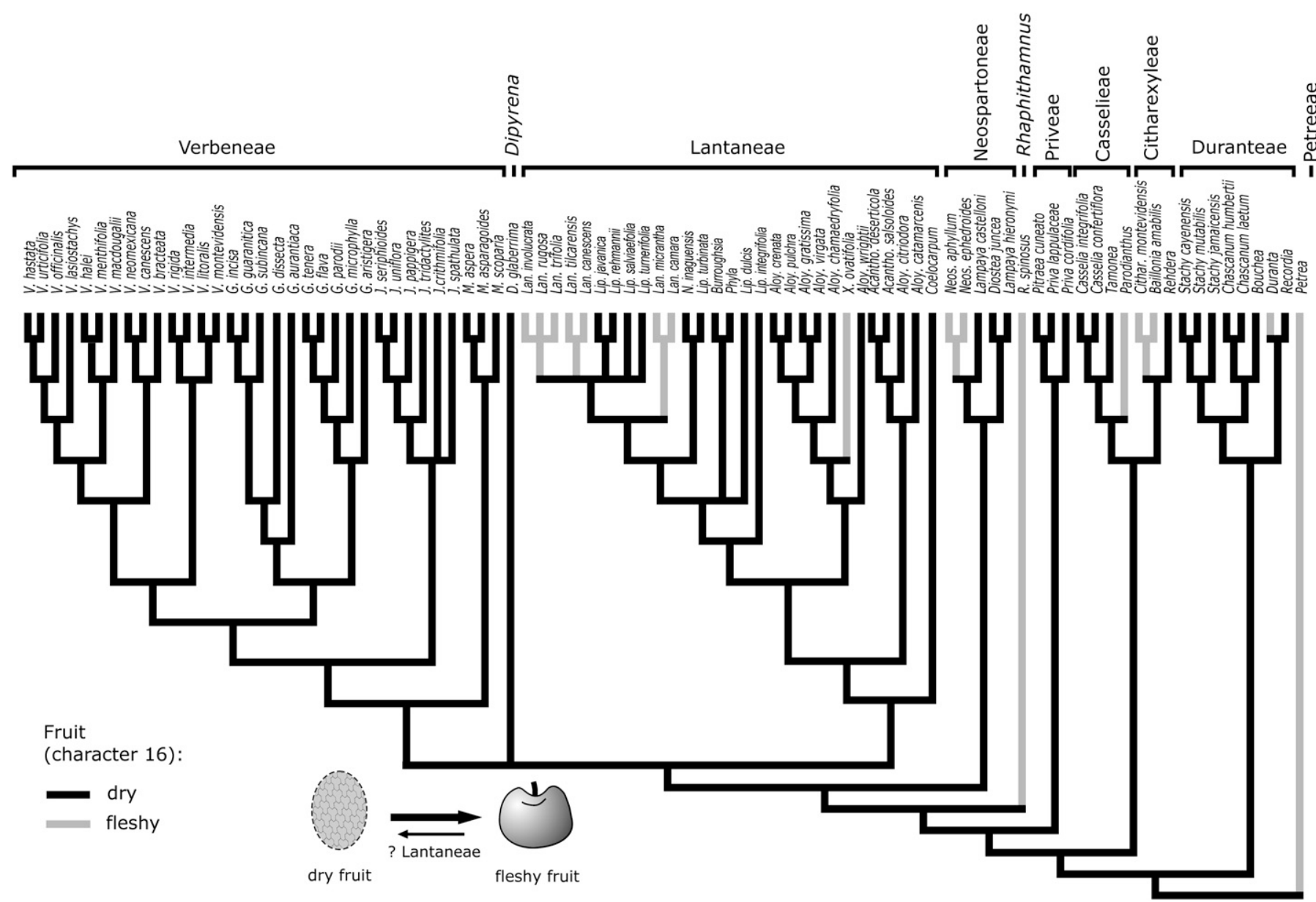

Fig. 6. Evolution of the type of fruit (character 16). This character is reconstructed as having 10 steps within Verbenaceae. 


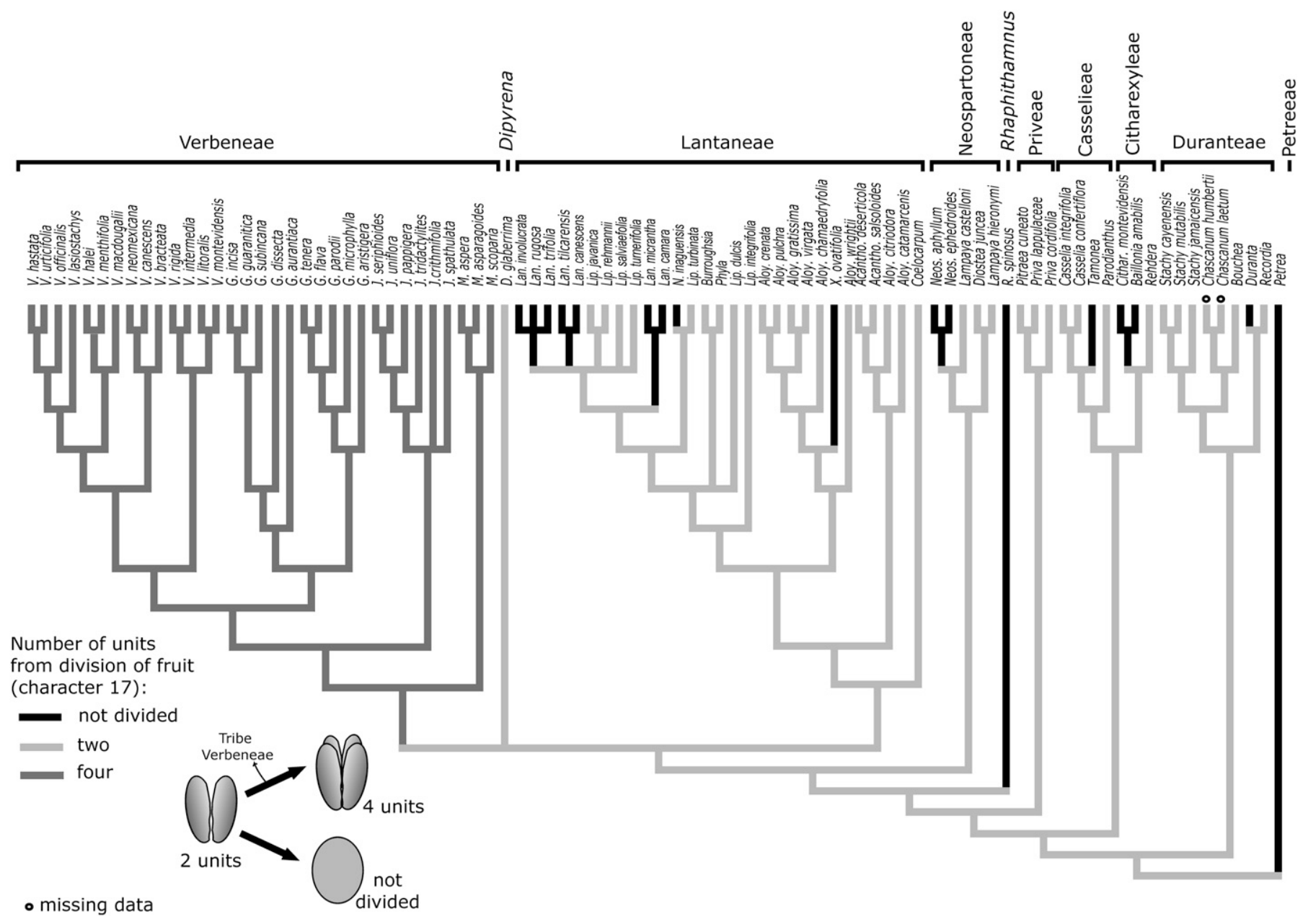

Fig. 7. Evolution of the number of units resulting from the of division of the fruit (character 17). This character is reconstructed as having 12 steps within Verbenaceae.

likely to be derived in Petreeae, as it is elsewhere in the family, and no reversals back to dry fruits are inferred.

Another important fruit trait is whether the fruit is divided into one of more units at maturity (char. 17, Fig. 7). The most frequent condition within Verbenaceae is a divided fruit with 2 dispersal units (either cluses or mericarps). Fruits in the most closely related families, including Thomandersiaceae (Wortley et al., 2007; Soltis et al., 2011; Refulio and Olmstead, unpublished data) are bicarpellate and multiovulate, and most often are capsules, with seeds as the dispersal unit. Thus, there is no direct inference from outgroups to bear on the question of ancestral fruit in Verbenaceae. The presence of 2 dispersal units is the result of the separation of the fruit along a longitudinal plane orientated on the median of the carpels (or carpel), the "medial plane" (Fig. 8A, B, "m.p.") that splits them into halves, as codified in character 18 (Fig. 9). Each dispersal unit consists of two adjacent half-carpels (tribes Citharexyleae, Casselieae (except Casselia), and genera Rhaphithamnus and Dipyrena), or half of one carpel (tribes Duranteae, Lantaneae, except Coelocarpum, Neospartoneae, and Casselia). The transformation to an undivided fruit has likely occurred independently numerous times from ancestors with 2 dispersal units, almost always correlated with a shift to fleshy fruits. A shift to 4-parted fruits has occurred only once in the possible ancestor of the tribe Verbeneae, and the innovation consists of the splitting of fruits along a second longitudinal "transverse plane" segregating carpels (Fig. 8A, "t.p.") as codified in character 19 (Fig. 10). This leads to an increase in the number of dispersal units from 2 to 4 (char. 17). Presence of 4 cluses has been used traditionally to distinguish Verbeneae (Troncoso, 1974), and our results show the character constitutes a nonhomoplasious synapomorphy for this tribe.

Although the number of seeds per dispersal unit has been used traditionally in Verbenaceae systematics (e.g., Troncoso, 1974; Briquet, 1895), we did not code this character, because it results from the correlation between the number of carpels (char. 15, Fig. 5), which are biovulate, and the separation of the ovary (chars. 18 and 19, Figs. 9, 10) along one or two longitudinal planes (Fig. 8). Furthermore, the repeated parallel abortion of one carpel (char. 15, Fig. 5) does not always result in a net change in the number of dispersal units, because this last depends also on the separation of the ovary (chars. 18 and 19, Figs. 9, 10). In schizocarpic fruits, two-seeded mericarps come from a bicarpellate ovary that separates only along the medial plane of the ovary; whereas one-seeded units (cluses) originate from an unicarpellate ovary that also separates along the medial plane of the ovary, or from a bicarpellate ovary that separates along both the medial and transverse plane. Taxa with fleshy fruit may produce pyrenes, and these can be two-seeded (e.g., 


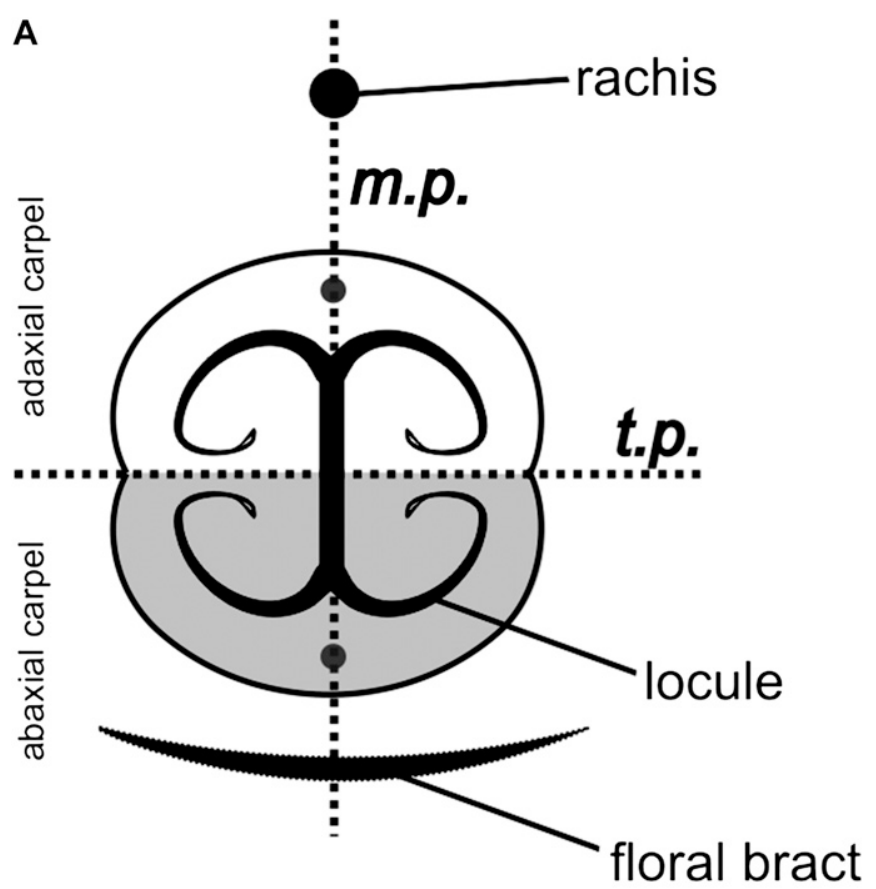

B

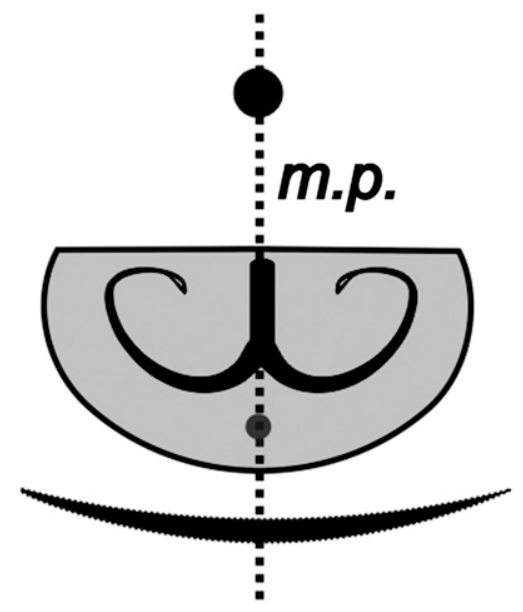

Fig. 8. Schematic diagram illustrating Verbenaceae ovary transverse cross section, showing carpel orientation and planes of ovary fragmentation. Line representing transverse plane labeled "t.p." delimits adaxial and abaxial carpels. Line representing medial plane shown as "m.p." splits carpels (or carpel) into halves. (A) Bicarpellate ovary: (1) separation along medial plane "m.p." can result into two mericarps, each one 2 -seeded, if a dry squizocarpic fruit, or two 2-seeded pyrenes, if a fleshy fruit; and (2) separation along medial plane "m.p." and transverse plane "t.p." results in four 1-seeded cluses. (B) Unicarpellate ovary, separation along medial plane "m.p." results into two cluses.

Lantana, Neosparton, and Petrea), four-seeded (Citharexyleae, except for Rehdera), or up to 8-seeded (Duranta), depending on the number of carpels. In Rhaphithamnus, the fruit is not divided but there are two pyrenes, and each is two-seeded, because both carpels are separated along the medial plane.

A narrow cluse base (char. 20) (Appendix S15, see Supplementary Data with the online version of this article), has been a diagnostic trait for Junellia (Botta, 1989), whereas both Glandularia and Verbena show an enlarged cluse base. In the tribe Verbeneae the origin of a narrow cluse base is reconstructed ambiguously. Most probably a narrow cluse base has evolved twice indepen- dently in both the ancestor of Mulguraea and in that of Junellia (Fig. 11, asterisk), rendering an enlarged cluse base a plesiomorphic state for Verbena + Glandularia. However, a unique origin of this trait in the likely ancestor of Verbeneae, with a possible later reversal in Verbena + Glandularia, cannot be ruled out with these data. Elsewhere in the family Verbenaceae, this trait can be expressed as a broad base, except where the fruits are undivided.

The evolution of the basic chromosome number (char. 21, not shown) is impossible to reconstruct in the family because of lack of information for many members. The common ancestor of tribe Verbeneae, is unambiguously reconstructed as $x=10$, as inferred by Yuan and Olmstead (2008a), although we cannot be certain if this is a synapomorphy or a plesiomorphy. The sister relationship of Verbena $(x=7)$ and Glandularia $(x=5)$ makes it impossible to know whether there was a sequential reduction from $x=10$, to $x=7$, and to $x=5$, or if both of those lineages are derived independently from ancestors with $x=10$. As Yuan and Olmstead (2008a) indicate, these results contradict the hypothesis of an origin of Junellia by polyploidy from ancestors with $x=5$ (Poggio et al., 1988; Botta and Brandham, 1993).

All previous classifications of Verbenaceae relied on some combination of carpel anatomy, fruit morphology, and inflorescence structure to circumscribe tribes (Schauer, 1847; Briquet, 1895; Troncoso, 1974; Sanders, 2001; Atkins, 2004). Despite differences among these classifications (depending on which traits were emphasized), all included two or more tribes that were in conflict with the molecular phylogenetic relationships as reconstructed by Marx et al. (2010). Inflorescence structure was reconstructed as two characters (characters 3 and 4), one of which is highly homoplastic. The loss of a terminal florescence (char. 3), and subsequent development of indeterminate growth in the inflorescence, is inferred to have occurred four times (Fig. 2), but the loss of axillary florescences (char. 4), resulting in a monobotrya (e.g., a unique terminal spike), may have occurred as many as $12-15$ times (Fig. 3). Similarly, the characters related to carpel anatomy and fruit morphology (chars. 15-17) also are highly homoplastic (Figs. $1,5-7)$. The difficulty with which carpel number is interpreted has misled nearly all previous workers who constructed classifications of Verbenaceae. Only Junell (1934), whose recommendations for restructuring the classifications of Lamiaceae and Verbenaceae were ignored for nearly 60 years (Cantino et al., 1992), correctly interpreted the carpel anatomy of Verbenaceae.

Conclusions-Synapomorphic morphological characters in Verbenaceae-The examined morphological and chromosome characters supporting the monophyly of groups inferred by phylogenetic analyses of molecular data are summarized in Fig. 11. Different combinations of characters states of the four kinds examined (e.g., habit and vegetative morphology, inflorescence and floral morphology, ovary and fruit morphology, and chromosome number) support tribal relationships within Verbenaceae.

It is difficult to infer synapomorphic traits for the tribe Petreeae, since it is the first diverging tribe within Verbenaceae and no sister families of Verbenaceae were sampled for comparison. However, three morphological synapomorphies from the fruit probably support this tribe, i.e., the entire, undivided (char. 17, state 0 and char. 18, state 0 ), and fleshy fruit (char. 16, state 1). Also, reduction to one carpel, through abortion, is another likely synapomorphy. In a separate analysis, Rueda (1994) identified bulbous-based hairs on the leaves and rounded lobes of the calyx (vs. dentate calyx lobes) as synapomorphies of Petreeae. However, he surveyed these traits only for a small number of putatively related genera. 


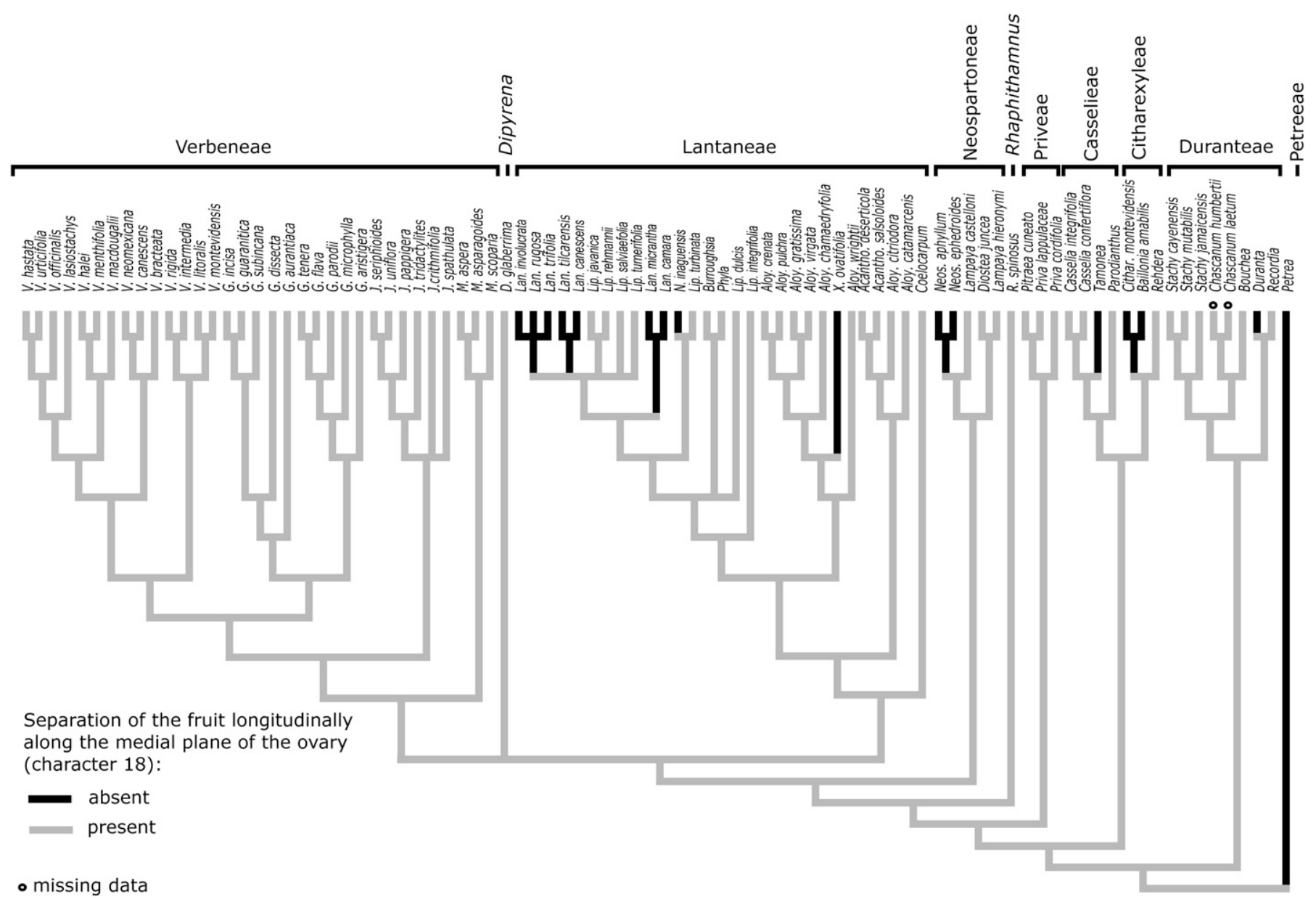

Fig. 9. Evolution of the separation of the fruit longitudinally along the medial plane of the ovary (character 18). This character is reconstructed as having 10 steps within Verbenaceae.

No synapomorphic traits could be found for tribe Duranteae. However the clade of Stachytarpheta + Bouchea + Chascanum is supported by three synapomorphies, i.e., suffrutescent habit (char. 1, state 1), pedicellate flowers (char. 5 , state 1 ), and probably the absence of an adaxial staminode (char. 9, state 0).

The tribe Citharexyleae also has no apparent synapomorphies. The absence of evident morphological synapomorphies for Citharexyleae and Duranteae, and their placement as consecutive branches on the phylogenetic tree of Verbenaceae, helps explain why the genera Citharexylum and Duranta were united in nearly all previous classifications (Marx et al., 2010).

Tribe Casselieae is supported by two morphological synapomorphies, i.e., homothetic pleiobotrya (absence of terminal florescence, char. 3 , state 1) and probably also absence of an adaxial staminode (char. 9, state 0 ).

Tribe Priveae is supported by one morphological synapomorphy: suffrutescent habit (char. 1, state 1).

Tribe Neospartoneae is supported by two morphological synapomorphies, unicarpellate ovary (char. 15, state 0 ) and sessile flowers (char. 5, state 1).

Tribe Lantaneae is supported by two morphological synapomorphies, short style (char. 11, state 0 ) and entire stigma (char. 12, state 0). Within Lantaneae, all genera except Coelocarpum form a monophyletic group supported by three morphological traits, i.e., pedicellate flowers (char. 5, state 0), a 4-toothed calyx (char. 6, state 1), and unicarpellate ovaries (char. 15, state 0 ). The clade comprising Lantana, Lippia, Aloysia, and Xeroaloysia is supported by only one synapomorphy, a homothetic pleiobotrya (absence of terminal florescence, char. 3, state 1). The Lippia/Lantana clade is supported by one synapomorphy, a bilobed calyx (char. 6, state 0 ).

In the genus Rhaphithamnus homothetic pleiobotrya (absence of terminal florescence, char. 3, state 1), and fleshy (char. 16, state 1), undivided (char. 17, state 0) fruits, are autapomorphic traits.

In the monotypic genus Dipyrena, a calyx partially covering the fruit (char. 14, state 1) and probably monobotrya inflorescences (absence of axillary florescences, char. 4, state 1) are both autapomorphic traits.

The current circumscription of the tribe Verbeneae is supported by the separation of the fruit longitudinally along the transverse plane of the ovary (char. 19, state 1), a nonhomoplasious synapomorphy. This innovation, coupled with the plesiomorphic condition that separates the fruit longitudinally along the medial plane of the ovary (char. 18), results in the separation of the fruit into 4 units, called cluses (char. 17, state 2), a characteristic only found in this tribe, and present in all its members. The Verbeneae is also supported by the suffrutescent habit (char. 1, state 1) 


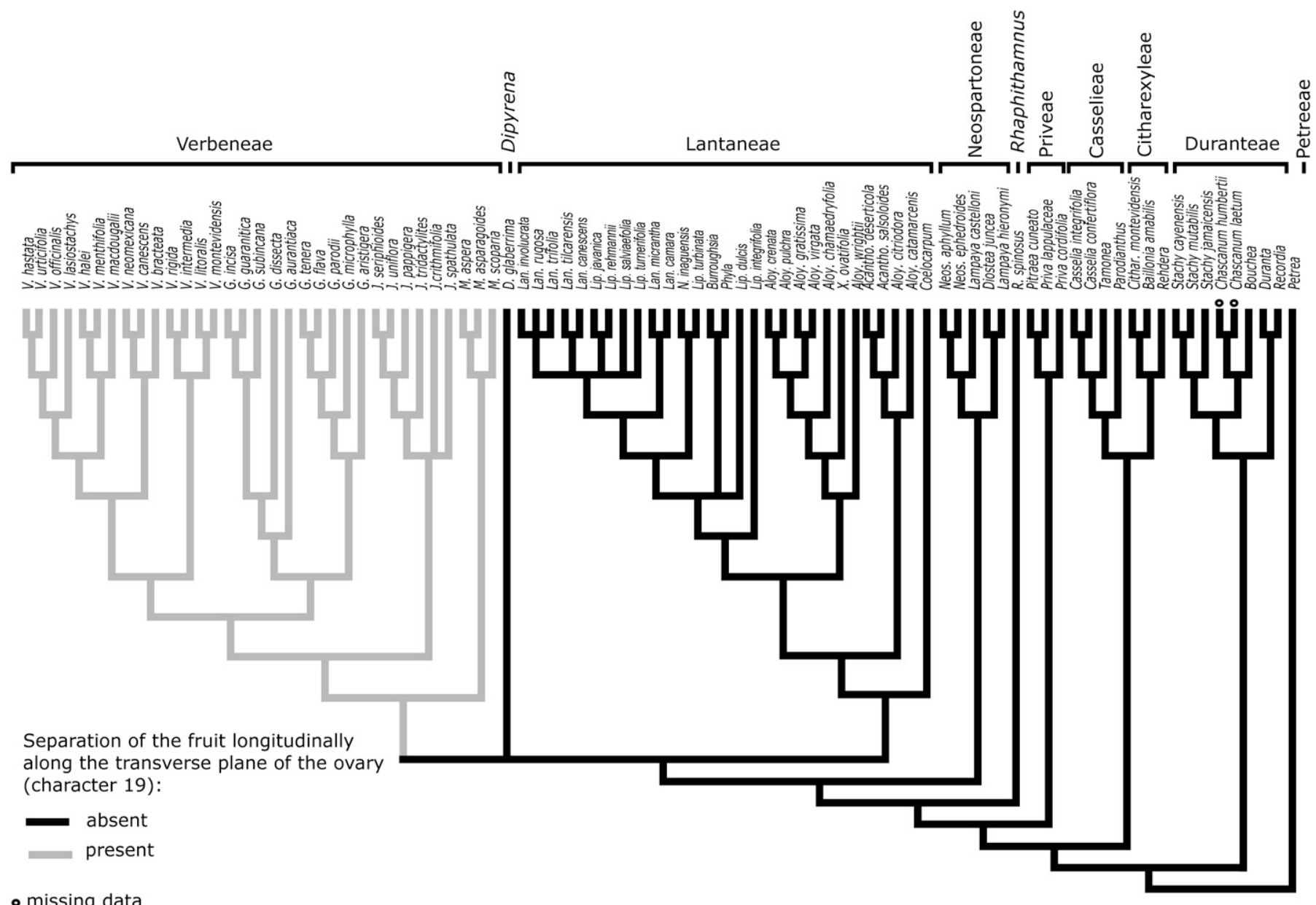

missing data

Fig. 10. Evolution of the separation of the fruit longitudinally along the transverse plane of the ovary (character 19). This character is reconstructed as having one step within Verbenaceae.

and probably by sessile flowers (char. 5, state 1). Traditional traits employed to distinguish Verbeneae (Troncoso, 1974; Atkins, 2004), for example, divided leaf blades (char. 2, state 1), dry fruit (char. 16, state 0), sessile flowers (char. 5, state 1) arranged in terminal florescences (char. 3, state 0 ), presence of glandular anther connective (char. 7, state 1), and bilobed stigma (char. 12, state 1) are inferred to be homoplastic within, or plesiomorphic for this tribe. The monophyly of the Verbena + Glandularia clade is supported by one synapomorphy, herbaceous habit (char. 1, state 2). The monophyly of the genus Verbena is supported by the short style (char. 11, state 0) and the basic chromosome number $x=7$ (char. 21, state 1), whereas Glandularia is supported by presence of divided leaf blades (char. 2, state 1), glandular anther appendices (char. 8, state 1), and the basic chromosome number $x=5$ (char. 21, state 0 ). Schauer (1847) had distinguished section Glandularia (included within Verbena) by the presence of glandular anther appendices. Numerous authors followed Schauer's criteria treating Glandularia as a group under Verbena (Briquet, 1895; Perry, 1933; Lewis and Oliver, 1961; Moldenke, 1940, 1942a, 1942b, 1971, 1973, 1983, among others; Macbride, 1960; Raj, 1983; Munir, 2002). Monophyly of Junellia is supported by the character of the narrowed cluse base (char. 20, state 1), although this is ambiguous, as stated above. A clade within Junellia, which
Peralta et al. (2008) referred to as section Junellia, is supported by two synapomorphic traits, enlarged style base (char. 13, state 1) and shrubby or small tree habit (char. 1, state 0 ). The genus Mulguraea is supported by three morphological synapomorphies, i.e., connective tissue surpassing thecae (char. 7, state 1), monobotrya inflorescences (absence of axillary florescences, char. 4, state 1), and a narrowed cluse base (char. 20, state 1), although the latter two may have other interpretations.

The clade that groups all Verbenaceae tribes except Duranteae and Petreeae is supported by the presence of bicarpellate ovaries (char. 15, state 1), although this is likely to be the ancestral state in the family. The clade from tribe Priveae to tribe Verbeneae is supported by the presence of a bilobed stigma (char. 12, state 1), and the clade from Rhaphithamnus to Verbeneae is supported by long styles (char. 11, state 1). Furthermore, the clade of Lantaneae + Dipyrena + Verbeneae is supported by the absence of an adaxial staminode (char. 9, state 0), although there is some ambiguity in the reconstruction of this trait.

Reconstruction of the evolutionary history of morphological traits allows us to suggest that the putative ancestor of the family Verbenaceae had a shrubby or small tree habit, entire leaf blades, heterothetic pleiobotrya inflorescences (terminal and axillary florescences) with pedicellate flowers, a 5-toothed calyx, unappendaged anthers with the connective not surpassing thecae, one 


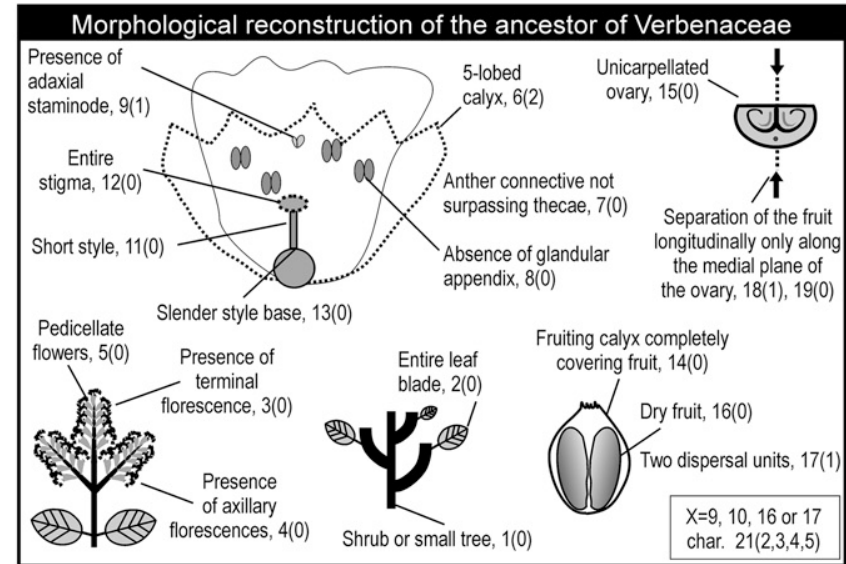

+one of the two equally parsimonious
reconstructions (see discussion for details)

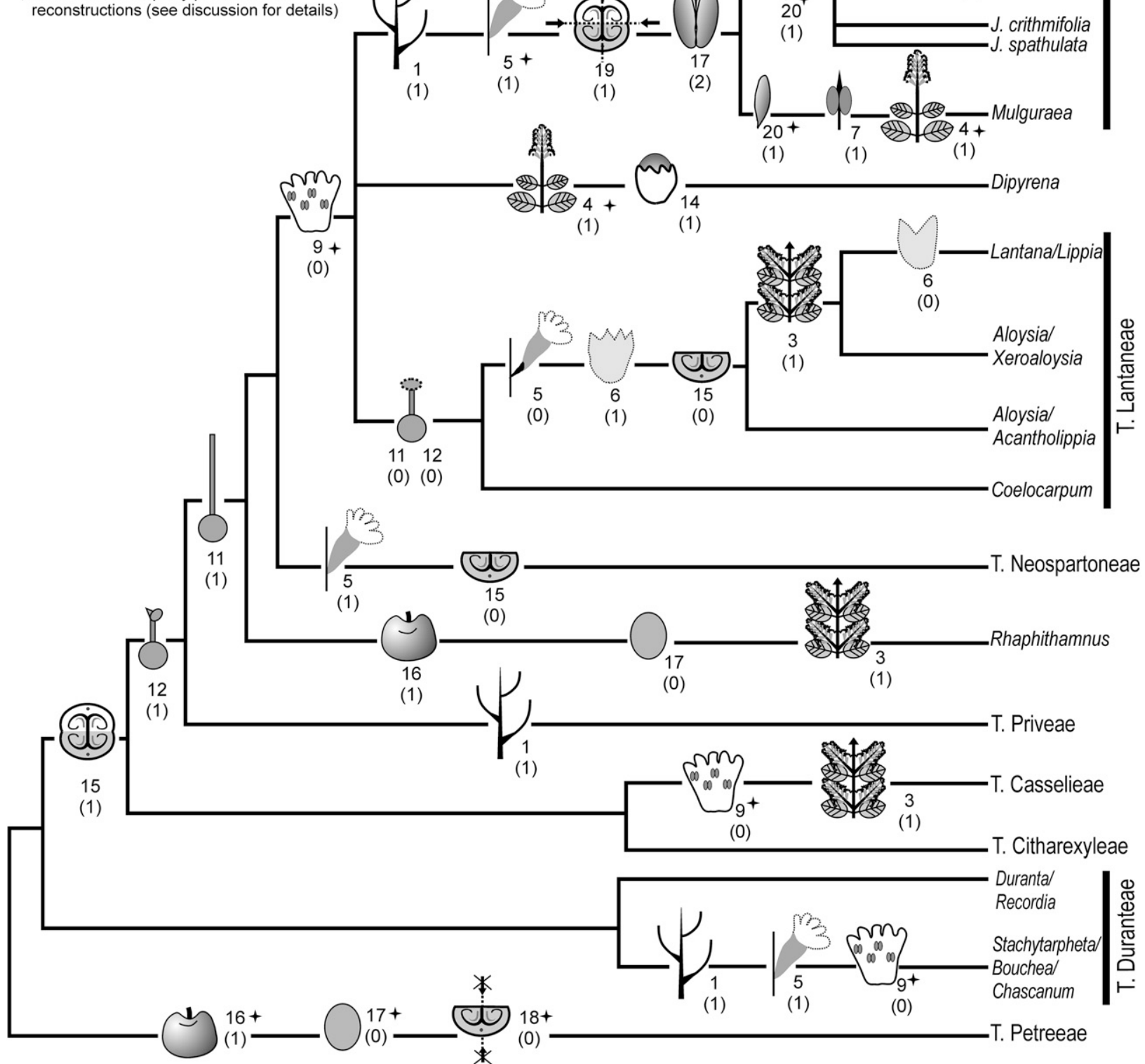

Fig. 11. Examined synapomorphic characters mapped onto a simplified version of the tree depicting relationships of Verbenaceae used elsewhere in this paper. Numbers correspond to those characters listed and described in Appendix 1, with states in parentheses. Probable plesiomorphies of the ancestor of Verbenaceae are provided in the box. 
adaxial staminode, a short style with a slender base, an entire, unlobed stigma, a fruiting calyx completely covering the dry fruit, which was derived from a unicarpellate ovary, and separating longitudinally along the medial plane into two dispersal units, and with a basic chromosome number of $x=9,10,16$, or 17 (Fig. 11).

In this study we carried out an exhaustive search for morphological characters that might be synapomorphies within Verbenaceae with a special focus on tribes Verbeneae, based on our knowledge of the group (O'Leary, 2007), and Lantaneae (LuIrving and Olmstead, in press). Characters traditionally employed in the classification of Verbenaceae were taken into consideration, since one main objective was to analyze their evolution within the family and principally in relation to each tribe. Many of the characters traditionally employed in classification have proven to be very homoplastic, or have not been shown to support relationships within the family. Moreover, traditional assumptions concerning character polarity have been shown to be incorrect in some cases. More detailed studies within other tribes, working with larger samples, and cryptic (and historically unused) characters, may yet identify morphological traits diagnostic for additional clades.

Online Supplemental Materials-The online version of this publication has links to figures which are not essential for a basic understanding of the main paper but may help in its comprehension.

\section{LITERATURE CITED}

Atkins, S. 2004. Verbenaceae. In J. W. Kadereit [ed.], The families and genera of flowering plants, vol. 7, 449-468. Springer-Verlag, Berlin, Germany.

AtKins, S. 2005. The genus Stachytarpheta (Verbenaceae) in Brazil. Kew Bulletin 60: 161-272.

Böhle, U. R., H. H. Hilger, and W. F. Martin. 1996. Island colonization and evolution of the insular woody habit in Echium L. (Boraginaceae). Proceedings of the National Academy of Sciences, USA 93: 11740-11745.

Botta, S., and P. E. Brandham. 1993. The taxonomic significance of chromosome number in Junellia (Verbenaceae). Kew Bulletin 48: 143-150.

BоттA, S. M. 1979. Las especies del género Aloysia (Verbenaceae). Darwiniana 22: 67-108.

BоттA, S. M. 1989. Estudios en el género sudamericano Junellia (Verbenaceae-Verbenoideae) I. Delimitación y tratamiento infragenérico. Darwiniana 29: 371-396.

BоттA, S. M. 1993. Notas en el género Glandularia (VerbenaceaeVerbenoideae) III. Estudio taxonómico de las especies patagónicas. Parodiana 8: 9-36.

Вотта, S. M. 1999. Verbenaceae. In N. M. Correa [ed.], Flora Patagónica, vol. 8, part 6, 147-195. Colecçion Cientifica del Instituto Nacional de Tecnologia Agropecuaria, Buenos Aires, Argentina.

Briquet, J. 1895. Verbenaceae. In A. Engler and K. Prantl [eds.], Die natürlichen Pflanzenfamilien, vol. 4, part 3a, 132-182. W. Engelmann, Leipzig, Germany.

Calviño, C. I., S. G. Martinez, and S. R. Downie. 2008. Morphology and biogeography of Apiaceae subfamily Saniculoideae as inferred by phylogenetic analysis of molecular data. American Journal of Botany 95: $196-214$.

Calviño, C. I., P. M. Tilney, B. E. van Wyk, and S. R. Downie. 2006. A molecular phylogenetic study of southern African Apiaceae. American Journal of Botany 93: 1828-1847.

Cantino, P. D., R. M. Harley, and S. J. Wagstaff. 1992. Genera of Labiatae Status and classification. In R. Harley [ed.], Advances in Labiatae Science, 511-522. Royal Botanic Gardens, Kew, Richmond, UK.

Drewes, S. I., AND S. MarTínez. 1999. Morfología de las inflorescencias en Verbenaceae-Verbenoideae II: Tribu Petreeae. Darwiniana 37 209-218.
JunELL, S. 1934. Zur Gynäceummorphologie und Systematik der Verbenaceen und Labiaten: Nebst Bemerkungen über ihre Samenentwicklung. Symbolae Botanicae Upsalienses 4: 1-219.

Lewis, W. H., AND R. L. Oliver. 1961. Cytogeography and phylogeny of North American species of Verbena. American Journal of Botany 48: 638-643.

Lu-Irving, P., and R. G. Olmstead. In press. Untangling the evolution of problematic taxa using multiple loci: an example from Lantaneae (Verbenaceae). Botanical Journal of the Linnean Society in press.

Macbride, J. F. 1960. Flora of Peru: Verbenaceae. Field Museum of Natural History. Chicago, Illinois. Botanical series 13(5/2): 609-721.

Maddison, W. P., AND D. R. MAdDison. 2005. Mesquite: A modular system for evolutionary analysis, vers. 1.06. http://mesquiteproject.org

Martínez, S., S. Botta, and M. E. Múlgura. 1996. Morfología de las inflorescencias en Verbenaceae-Verbenoideae I: Tribu Verbeneae. Darwiniana 34: 1-17.

Martínez, S., AND M. E. Múlgura. 1997. Yemas axilares múltiples, morfología y tipología de la inflorescencia en Duranta (VerbenaceaeCitharexyleae). Boletín de la Sociedad Argentina de Botánica 33: 113-122.

Marx, H., N. O’Leary, Y. Yuan, P. Lu-Irving, D. TanK, M. E. Múlgura, and R. Olmstead. 2010. A molecular phylogeny and classification of Verbenaceae. American Journal of Botany 97: 1647-1663.

Moldenke, H. N. 1940. Contributions to the flora of extra-tropical South America. Lilloa 5: 392-403.

Moldenke, H. N. 1942a. Contributions to the flora of extra-tropical South America IV. Lilloa 8: 397-435.

Moldenke, H. N. 1942b. Verbena, Verbenaceae. In C. L. Lundell et al. [eds.], Flora of Texas, vol. 3, 15-47. Texas Research Foundation, Renner, Texas, USA.

MoldenkE, H. N. 1971. Verbenaceae, Verbena. In I. L.Wiggins and D. M. Porter [eds.], Flora of the Galapagos Islands, 503-509. Stanford University Press, California, USA.

Moldenke, H. N. 1973. Verbenaceae, Verbena. In R. E. Woodson, R. W. Schery et al. [eds.], Flora of Panamá. Annals of the Missouri Botanical Garden 60(1): 41-148.

Moldenke, H. N. 1983. Verbenaceae. In M. D. Dassanayake and F. A. Fosberg [eds.], A revised handbook to the flora of Ceylon, vol. 4, 196487. Amerind Publishing Company, New Delhi, India.

Múlgura, M. E., S. Martínez, S. Atkins, and A. D. Rotman. 2002. Morfología de las inflorescencias en Verbenaceae-Verbenoideae II: Tribu Lantaneae p.p. Darwiniana 40: 1-15.

Múlgura, M. E., S. Martínez, and A. Suyama. 1998. Morfología de las inflorescencias en Lippia (Verbenaceae). Darwiniana 36: 1-12.

Munir, A. A. 2002. A taxonomic revision of the genus Verbena L. (Verbenaceae) in Australia. Journal of the Adelaide Botanical Garden 20: 21-103.

O'LeARY, N. 2007. Estudios sistemáticos y filogenéticos en el género Verbena L. (Verbenaceae). Ph.D. dissertation, Facultad de Ciencias Exactas y Naturales, Universidad de Buenos Aires, Buenos Aires, Argentina.

O'Leary, N., AND M. E. Múlgura. 2010. A taxonomic revision of Casselia (Verbenaceae), a genus endemic to the South American Cerrado and Mata Atlántica biogeographic provinces. The Journal of the Torrey Botanical Society 137: 166-179.

O’Leary, N., and M. E. Múlgura. 2012. A taxonomic revision of the genus Phyla (Verbenaceae). Annals of the Missouri Botanical Garden 98: 578-596.

O’Leary, N., M. E. Múlgura, and O. Morrone. 2007a. Revisión taxonómica de las especies del género Verbena (Verbenaceae): Serie Pachystachyae. Annals of the Missouri Botanical Garden 94: 571-621.

O’Leary, N., M. E. Múlgura, and O. Morrone. 2007b. New combinations in South American Glandularia J. F. Gmel. (Verbenaceae). Novon 17: 503-511.

O’Leary, N., M. E. Múlgura, and O. Morrone. 2010. Revisión taxonómica de las especies del género Verbena L. (Verbenaceae) II: Serie Verbena. Annals of the Missouri Botanical Garden 97: 365-428.

O'Leary, N., and P. Peralta. 2007. Nuevas combinaciones en el género Glandularia (Verbenaceae). Darwiniana 45: 218-230. 
O’Leary, N., P. Peralta, and M. E. Múlgura. 2008. A taxonomic revision of the genus Tamonea (Verbenaceae). Botanical Journal of the Linnean Society 157: 357-371.

O’Leary, N., P. Peralta, and M. E. Múlgura. 2011. Sinopsis taxonómica y nomenclatural del género Junellia (Verbenaceae). Darwiniana 49: $47-75$.

O’Leary, N., Y.-W. Yuan, A. Chemisquy, and R. G. Olmstead. 2009. Reassignment of species of paraphyletic Junellia s.l. to the new genus Mulguraea (Verbenaceae) and new circumscription of genus Junellia: Molecular and morphological congruence. Systematic Botany 34: 777-786.

Panero, J. L., J. F. Ortega, R. K. Jansen, and A. Santos-Guerra. 1999. Molecular evidence for multiple origins of woodiness and a New World biogeographic connection of the Macaronesian Island endemic Pericallis (Asteraceae: Senecioneae). Proceedings of the National Academy of Sciences, USA 96: 13886-13891.

Peralta, P. 2010. Sistemática y filogenia del género Glandularia. Ph.D. dissertation, Facultad de Ciencias Naturales, Universidad Nacional de La Plata, La Plata, Argentina.

Peralta, P., M. E. Múlgura, S. S. Denham, and S. M. Botta. 2008. Revisión del género Junellia (Verbenaceae). Annals of the Missouri Botanical Garden 95: 338-390.

Perry, L. M. 1933. A revision of the North American species of Verbena. Annals of the Missouri Botanical Garden 20: 239-356, 358-362.

Poggio, L., E. Greizerstein, and S. Botta. 1988. Estudios cromosómicos en Verbenaceae. Boletín de la Sociedad Argentina de Botánica 25: 542-545.

RAJ, B. 1983. A contribution to the pollen morphology of Verbenaceae. Review of Palaeobotany and Palynology 39: 343-422.

RuedA, R. M. 1994. Systematics and evolution of the genus Petrea (Verbenaceae). Annals of the Missouri Botanical Garden 81: 610-652.

SANDERS, R. W. 2001. The genera of Verbenaceae in the southeastern United States. Harvard Papers in Botany 5: 303-358.

Schäferhoff, B., A. Fleishmann, E. Fischer, D. C. Albach, T. Borsch, G. Heubl, AND K. F. MülLer. 2010. Towards resolving Lamiales relationships: Insights from rapidly evolving chloroplast sequences. $B M C$ Evolutionary Biology 10: 352.
Schauer, J. C. 1847. Verbenaceae. In A. P. De Candolle [ed.], Prodromus systematis naturalis regni vegetabilis, vol. 11, 522-700. Sumptibus sociorum Treuttel et Würtz, Parisiis, France.

SchNACK, B. 1964. Bases naturales de la separación genérica de Verbena y Glandularia (Verbenáceas). Notas de la Comisión de Investigaciones Científicas de La Plata 2: 3-12.

Schnack, B., AND G. Covas. 1944. Nota sobre la validez del género Glandularia (Verbenaceae). Darwiniana 6: 469-476.

Schnack, B., AND G. Covas. 1946. Nota taxonómica sobre el género Glandularia (Verbenaceae). Boletín de la Sociedad Argentina de Botánica 1: 282-284.

Sell, Y. 1976. Tendances évolutives parmi les complexes inflorescentiels. Revue Generale de Botanique 83: 247-267.

SELl, Y. 1980. Physiological and phylogenetic significance of the direction of flowering in inflorescence complexes. Flora 169: 282-294.

Soltis, D. E., S. A. Smith, N. Cellinese, K. J. Wurdack, D. C. Tank, S. F. Brockington, N. F. Refulio-Rodriguez, et AL. 2011. Angiosperm phylogeny: 17-genes, 640 taxa. American Journal of Botany 98: 704-730.

Troll, W. 1964. Die Infloreszenzen. Typologie und Stellung in Aufbau des Vegetationskörpers, vol. I. G. Fisher, Stuttgart, Germany.

Troll, W. 1969. Die Infloreszenzen. Typologie und Stellung in Aufbau des Vegetationskörpers, vol. II, part 1. G. Fisher, Stuttgart, Germany.

Troncoso, N. S. 1974. Los géneros de Verbenaceas de Sudamerica extratropical. Darwiniana 18: 295-412.

Wortley, A. H., G. J. Harris, and R. W. Scotland. 2007. On the taxonomy and phylogenetic position of Thomandersia. Systematic Botany 32: 415-444.

Yuan, Y.-W., C. Liu, H. E. Marx, and R. G. Olmstead. 2010. An empirical demonstration of using PPR (pentatricopeptide repeat) genes as phylogenetic tools: Phylogeny of Verbenaceae and the Verbena complex. Molecular Phylogenetics and Evolution 54: 23-35.

Yuan, Y.-W., AND R. G. Olmstead. 2008a. A species-level phylogenetic study of the Verbena complex (Verbenaceae) indicates two independent intergeneric chloroplast transfers. Molecular Phylogenetics and Evolution 48: 23-33.

Yuan, Y.-W., and R. G. Olmstead. 2008b. Evolution and phylogenetic utility of the PHOT gene duplicates in a recently diversified group: Dramatic intron size variation and footprint of ancestral recombination. American Journal of Botany 95: 1166-1176.

APPENDIX 1. Morphological characters and character states examined in this study are arranged by class, with explanatory comments. The numbers of each character and its states correspond to those presented in Appendix S1 (see Supplemental Data with the online version of this article).

\section{Habitat and vegetative morphology}

1. Habit: 0 , shrub or small tree; 1 , suffrutescent; 2 , herb.

Woodiness distributed throughout the above-ground parts of the plant has been coded as shrub or small tree. Presence of persistent woody stems only on the base of the plant has been coded as suffrutescent, and complete absence of woody structures has been coded as herb.

2. Leaf blade incision: 0 , entire; 1 , divided.

Verbenaceae leaf blades are always simple with differences in the division of the blade (e.g., lobed, dissected). Leaf blades were coded either as entire when there is no incision, or divided, irrespective of the degree of its incision.

\section{Inflorescence and floral morphology}

3. Terminal florescence: 0 , present; 1 , absent.

A florescence is the minimum expression of flower arrangement. In Verbenaceae florescences are either racemes or spikes varying in arrangement, spacing, number of flowers, and development of its rachis, this last character sometimes results in capitulate florescences. Florescences are organized into simple or compound inflorescences, and in terminal or axillary position. Recent studies (Martínez et al., 1996; Martínez and Múlgura, 1997; Múlgura et al., 1998; 2002; Drewes and Martínez, 1999) have found in Verbenaceae: (1) monobotrya (simple inflorescence, just one terminal florescence, see Múlgura et al., 2002: 11, Fig. 5C,D; O’Leary and Peralta, 2007: 225,
Fig. 4A); (2) heterothetic pleiobotrya (compound inflorescence, many florescences axillary and terminal, see Martínez at al., 1996: 4, Fig. 2); and (3) homothetic pleiobotrya (compound inflorescence, many florescences only axillary, see Múlgura et al., 2002: 5, Fig. 2; O’Leary and Múlgura, 2012: 580, Fig. 1A), and considered these cases to be evolutionary stages of one character. In this study, we coded these characteristics as two different characters (chars. 3 and 4) because we understand that the presence of a terminal florescence is independent of the presence of axillary florescences. Therefore for character 3, plants with monobotrya and heterothetic pleiobotrya are here coded as terminal florescence present, and plants with homothetic pleiobotrya are coded as terminal florescence absent.

4. Axillary florescences: 0 , present; 1 , absent.

Plants with heterothetic and homothetic pleiobotrya are coded as axillary florescences present, and monobotrya or absence of axillary florescences are coded as absent. See observation under character 3 .

5. Flowers: 0, pedicellate; 1 , sessile.

Flowers can be arranged in racemes or spikes, in the first case flowers are briefly pedicellate, in the second they are sessile.

6. Calyx dentition: 0, bilobed or 2-toothed; 1, 4-toothed; 2, 5-toothed.

In Verbenaceae, the calyx is a short or long tube, and its apex can be 2-, 4-, or 5-toothed (Appendix S6, see Supplemental Data with the online version of this article). 
APPENDIX 1. Continued.

7. Anther connective tissue: 0 , not surpassing the thecae; 1 , surpassing the thecae.

Verbenaceae flowers have anthers with two thecae, which are joined to each other and to the filament by the connective tissue. Sometimes this tissue can be prominently developed with an apiculate apex that surpasses the length of the theca. O'Leary et al. (2011: 22, Fig. 7E) illustrate stamens with anther connective tissue not surpassing thecae. Botta (1999: 191, Fig. $141 \mathrm{f}, \mathrm{f}$ ') shows stamens with anther connective tissue surpassing thecae.

8. Glandular anther connective appendix: 0 , absent; 1 , present.

Anther connective tissue in Verbenaceae is enlarged sometimes, as explained in character 7, and other times it appears as an apical and very obvious glandular anther appendix. In several cases the appendix can even protrude from the corolla limb (see O'Leary et al. 2011: 20, Fig. 6G). These cases are coded as present. In other cases the tissue does not enlarge to form a noticeable gland, but just a little glandular tissue is visible (e.g., Dipyrena, Pitraea, see Troncoso, 1974: 363, Fig. 20g), which in this study this has been coded as absent, as no real appendix is developed.

9. Adaxial staminode: 0 , absent; 1 , present.

Staminodes are generally reduced to a brief antherless filament. Verbenaceae flowers normally have 4 fertile stamens, inserted on the corolla and alternating with the corolla lobes. In some genera 1 staminode is present, and always in the ventral adaxial position, representing a fifth sterile stamen (see Troncoso, 1974: 363, Fig. 20f). Whenever a plant has at least one flower bearing a staminode, even if staminodes are absent in other flowers from the same individual, the character is coded as present. The lack of any staminodes is coded as absent.

10. Pair of adaxial lateral stamens: 0 , fertile; 1 , sterile and reduced to staminodes.

In Stachytarpheta only 2 stamens are fertile, and the other two in adaxial lateral position are reduced to sterile staminodes (see Atkins, 2005: 192, Fig. 5D,J).

11. Style length: 0 , short ( $<3$ times ovary length); 1 , long ( $>3$ times ovary length).

In Verbenaceae flowers the ovary is superior with its style apical and terminal. Some taxa have styles always shorter than $2 \times$ the ovary length (see O'Leary and Múlgura, 2010: 170, Fig. 3H; O'Leary and Múlgura, 2012: 587, Fig. 4H), while other taxa have long styles, always much longer than $4 \times$ the ovary length (see Atkins, 2005: 192, Fig. 5D,J; O'Leary and Peralta, 2007: 220, Fig. 1G). No intermediate forms are known.

12. Stigma: 0 , entire (unlobed); 1 , bilobed.

The simple style can terminate with capitate, oblique, or lateral stigmatic tissue, and coded as entire (unlobed) (e.g., see O'Leary and Múlgura, 2012: 587, Fig. 4H, capitate; Troncoso, 1974: 343, Fig. 11e, oblique or lateral). Or, the style apex can be bilobed with only one lobe stigmatic (e.g., see O'Leary et al., 2007b: 507, Fig. 2E). and here coded as bilobed .

13. Style base: 0 , slender; 1 , enlarged.

In most Verbenaceae flowers, the style base is somewhat inserted at the apex of the ovary, and here coded as a slender style base. However, in some species of Junellia, the style base is enlarged and expands in fruit to partially or even completely cover the fruit, and here coded as an enlarged style base (Appendix S13, see Supplemental Data with the online version of this article).

\section{Ovary and fruit morphology}

14. Fruiting calyx: 0 , completely covering the fruit; 1 , partially covering the fruit; 2, not persistent.
The fruiting calyx has been coded as completely covering the fruit whenever no part of the fruit is visible, as in some Glandularia where the calyx teeth are fused and contorted, enclosing the fruit (e.g., see O'Leary et al., 2007b: 504, Fig. 1B,G). If any of the apical part of the fruit is visible, then coding is as partially covering the fruit (e.g., see O'Leary and Múlgura, 2010: 167, Fig. 1b,f). If the calyx falls during development of the fruit, then this has been coded as not persistent.

15. Number of carpels: 0 , one; 1 , two; 2 , more than two.

Verbenaceae ovaries can be unicarpellate, bicarpellate, or in Duranta 4-carpellate (exceptionally 5-carpellate). Each carpel bears 2 ovules and is 1-locular or, 2-locular by the inrolling of the carpel margin (Figure 8).

16. Fruit: 0 , dry; 1 , fleshy.

The fruits of Verbenaceae can be dry, generally schizocarpic, and splitting at maturity into 2 (e.g., see Troncoso 1974: 365, Fig. 21m) or 4 units (see O'Leary et al., 2007b: 508, Fig. 3E,F), or, exceptionally, not divided (e.g., as in Tamonea, see O'Leary et al., 2008: 360, Fig. 2E). Alternatively, the fruit can be fleshy, drupaceous, with 1 or 2 dry nuts, depending on the taxa, called pyrenes, each pyrene 2-seeded (see Troncoso, 1974: 324, Fig. 6i).

17. Number of units from division of the fruit: 0 , not divided; 1 , two; 2 , four.

In Verbenaceae a schizocarpic fruit can be divided into two or four units, depending on the number of partitions of the ovary. The partition along the "medial plane" (Figure 8, "m.p.") separates the fruit longitudinally into two units. A unicarpellate ovary (Figure 8B) partitions into two 1-seeded units, called cluses, each cluse representing half a carpel; a bicarpellate ovary (Figure 8A) partitions into two 2-seeded units, called mericarps, each one representing two adjacent half-carpels. In some taxa, a second partition segregating carpels along the "transverse plane" (Figure 8A, "t.p."), perpendicular to the "medial plane", also occurs, deriving four one-seeded units, again called cluses, because each one represents half a carpel. Whenever the fruit is fleshy (drupaceous) this character was coded as not divided. However, Tamonea is the only example of a dry fruit which does not split (not schizocarpic), and here also coded as not divided.

18. Separation of the fruit longitudinally along the medial plane of the ovary, splitting carpels (or carpel) into halves: 0 , absent; 1, present.

See observations under character 17 and Figure 8 "m.p.". Even if the fruit is drupaceous, there can be an internal separation which delimits pyrenes, as in Rhaphithamnus, but the number of dispersion units remains one (see Troncoso, 1974: 381, Fig. 29k, 1).

19. Separation of fruit longitudinally along the transverse plane (perpendicular to medial plane) of the ovary, segregating carpels: 0 , absent; 1 , present.

See observations under character 17 and Figure 8, "t.p.".

20. Cluse or mericarp base: 0 , enlarged; 1 , narrowed; 2 , not divided fruit.

The most frequent condition in Verbenaceae is an enlarged mericarp or cluse base with an internal fold of the commissural wall, here coded as enlarged (e.g., see Botta, 1989: 381, Fig. 2D,E). In a group of taxa within tribe Verbeneae, where cluse bases are narrowed and lack an internal fold of the commissural wall, this was coded as narrowed (e.g., see Botta, 1989: 381, Fig. 2B,C). But, whenever the fruit is dry but not divided (e.g., Tamonea), or is a fleshy drupaceous fruit, this character was coded as not divided fruit.

\section{Chromosome number}

21. Basic chromosome number: $0, x=5 ; 1, x=7 ; 2, x=9 ; 3, x=10 ; 4, x=16 ; 5$, $x=17 ; 6, x=18$.

This character was coded into seven states, representing all the different basic chromosome numbers that have been reported in Verbenaceae. 